\title{
Efectos del entrenamiento acuático y posterior desentrenamiento sobre la percepción e intensidad del dolor y el número de puntos sensibles de mujeres con fibromialgia
}

Pablo Tomas-Carus ${ }^{\mathrm{a}, \mathrm{b}}$, Armando Raimundo ${ }^{a}$, José C. Adsuar ${ }^{\mathrm{b}}$, Pedro Olivares ${ }^{\mathrm{b}}$ y Narcís Gusi ${ }^{\mathrm{b}}$

${ }^{2}$ Departamento de Deporte y Salud. Universidad de Évora. Évora. Portugal.

baboratorrio de Condición Física y Calidad de Vida. Universidad de Extremadura. Cáceres. España.

\section{RESUMEN}

Introducción y objetivos: El síntoma más frecuente y característico de la fibromialgia es el dolor generalizado y difuso. El propósito de este estudio fue evaluar los efectos de 12 semanas de entrenamiento en agua caliente y posterior desentrenamiento sobre la percepción e intensidad de dolor y número de puntos sensibles al dolor de mujeres con fibromialgia. Métodos: Treinta y cinco pacientes fueron distribuidas aleatoriamente en 2 grupos: un grupo experimental $(n=$ 18), que realizó 3 sesiones semanales de ejercicio físico de 60 min cada una, y el grupo control $(n=17)$, que no recibió dicho entrenamiento adicional. El dolor se evaluó usando las dimensiones de dolor del Fibromyalgia Impact Questionnarie y Short Form 36. También se evaluó el número de puntos sensibles al dolor.

Resultados: Después de 12 semanas de programa se observaron mejoras significativas en el grupo experimental respecto al grupo de control en la intensidad y percepción del dolor. Sin embargo, tras el período de desentrenamiento sólo se mantuvo la mejora en la dimensión de "dolor corporal" del Short Form 36. El número de puntos sensibles al dolor permaneció sin cambios en ambos grupos durante todo el protocolo de programa.

Conclusiones: Un programa de 12 semanas de entrenamiento en agua caliente, unido al tratamiento médico clásico, fue efectivo para reducir el dolor en mujeres con fibromialgia. Tras un período similar sin realizar entrenamiento físico las mejoras en dolor se mantuvieron parcialmente. Sin embargo, el programa de entrenamiento no tuvo efectos en la reducción del número de puntos sensibles al dolor.

PALABRAS CLAVE: Entrenamiento. Agua caliente. Dolor. Fibromialgia.

\section{ABSTRACT}

Introduction and objectives: The most frequent and characteristic symptom of fibromyalgia is generalized and diffuse pain. The purpose of this study was to evaluate the effects of 12 weeks of physical training in warm water and subsequent detraining on the perception and intensity of pain and the number tender points in women with fibromyalgia.

Methods: Thirty-five women with fibromyalgia were randomly assigned to 2 groups: an experimental group $(\mathrm{n}=$ 18), who exercised for $60 \mathrm{~min}$ in warm water 3 times a week, and a control group $(n=17)$, who did not receive the additional training. Pain was assessed using the dimensions of pain of the Fibromyalgia Impact Questionnaire and the Short Form-36. The number of tender points was also assessed.

Results: After the 12-week training program significant improvements were observed in the perception and intensity of pain in the experimental group compared with the control group. However, after the detraining period, only the improvement in the "body pain" dimension of the Short Form-36 was maintained. The number of tender points showed no significant change in either group during the 24week program.

Conclusions: Addition of the physical training program to conventional care was effective in decreasing pain in women with fibromyalgia. After the detraining period, the improvements in pain were partially maintained. However, the physical training program had no effect on the number of tender points.

KEY WORDS: Physical training. Warm water. Pain. Fibromyalgia

Correspondencia: Prof. De. Pablo Tomás Carús. Pavilhao Gimnosdesportivo da Universidade de Évora. Prolongamiento da Rua de Reguengos de Monsaraz, 14. 7000-727 Évora. Portugal. Correo electrónico: ptc@uevora.pt 